change and the appearance of cultural materials is unclear, this interesting association requires more investigation.

From the standpoint of early man studies, one of the major outstanding questions is the date of the KBS tuff. The date of this tuff is crucial because there is good evidence of the presence of the genus Homo below this level. The results of radiometric studies have been contradictory, ranging from 1.6 to 2.6 Myr BP for this tuff. As Cooke's paper indicates, the earlier date for the KBS tuff may be suspect on palaeontological grounds. Cooke's studies on fossil pigs has shown that tooth size in one taxon, Mesochoerus limnetes, found below the KBS tuff at East Rudolf most closely resembles that in specimens from the

\section{Hominid and the bathwater}

\section{W. W. Bishop}

Geology of the Olduvai Gorge: A Study of Sedimentation in a Semiarid Basin. By R. L. Hay. Pp. xvi + 203. (University of California: Berkeley, Los Angeles and London, 1976.) $£ 15.75$.

RECENT interest in Earth science has promoted fruitful growth of such 'interface' studies as geochemistry, geophysics, and geobiology. It comes as no surprise to see the common ground between geology and archaeology also attracting attention. What is unusual is to find, within the 200 pages of a single-author volume, a blue-print for the application of various disciplines to the study of sediments yielding hominids and artefacts. These include stratigraphy, geochronology, sedimentary petrography, mineralogy, isotope geochemistry and amino acid chemistry, to mention but a few.

On this substratum Dr Hay builds a sophisticated time framework for the past 2 Myr and reconstructs palaeoenvironmental settings for the hominids, their artefacts and, by inference, their activities in the changing palaeogeography of the Olduvai region.

Olduvai was the area where large scale excavations by Louis and Mary Leakey showed geologists, vertebrate palaeontologists and even some archaeologists, how local microstratigraphy could be studied to set early hominids and their palaeolithic took kits against a factual background from which to decipher the environment of burial and, with luck, the habitat of life. Dr Hay, with early experience of the stratigraphical complexity posed by arid intermontane basins in western USA, was the ideal successor to other geologists (Hans Reck, E. J. nearby Omo area dated to $2 \mathrm{Myr}$ BP.

This important volume contains a wealth of detailed and important information, and will be very useful at the professional level. Its information, however, will be less accessible to students. Although each of the three major sections is prefaced with an introduction, these are far too brief to really open the major issues and questions posed by each area of research. Such interdisciplinary studies are most valuable when they result in a synthesised and comprehensive view. Although such synthesis is missing here it is a minor defect in an otherwise fine volume.

G. E. Kennedy is Assistant Professor in the Department of Anthropology at the University of California, Los Angeles, California.

Wayland, P. J. H. Boswell, P. E. Kent and R. A. Pickering) who worked at Olduvai. It was fortunate that he appeared on the scene in 1962 after initial overconcern with alleged pluvial-interpluvial 'climatic stratigraphy' had been passed over in favour of a return to 'normal' stratigraphical and geological methods.

The finding of the skull of Australopithecus (Zinjanthropus) boisei in 1959 was the trigger mechanism for new investigations. Olduvai witnessed the first application of $\mathrm{K}-\mathrm{Ar}$ dating to rocks as young as 1 or 2 Myr. Dr Hay tabulates the $57 \mathrm{~K}-\mathrm{Ar}$ ages established for Bed I since the initial investigation by Curtis and Evernden, and discusses them in relation to fission-track dating and palaeomagnetic polarity data. Beds II to IV yield few reliable $\mathrm{K}-\mathrm{Ar}$ dates, but numerous radiocarbon ages are given spanning the past $30,000 \mathrm{yr}$ at Olduvai.

For the archaeologist the most important sections of the book are those presenting palaeogeographic reconstructions, both descriptive and visual (18 out of 27 maps in a total of 63 text figures), based upon detailed stratigraphical columns, which are also excellently illustrated by pull-out sections. These provide the factual and the interpretative environmental record against which Dr Hay records the hominid and artefact content of each formation. The final chapters present a synthesis in the form of a four-page evolutionary history of the Olduvai basin and a discussion which in 7 pages distils evidence for the pattern of hominid activities.

Despite its high price this is a book to purchase as well as to read, for its seems certain to become a 'classic'. It demonstrates how geochronology and the study of palaeoenvironments may be used to obtain full value out of both the fossil baby and the sedimentary bathwater.

W. W. Bishop was Professor of Geology at Queen Mary College, University of London, UK. He died on 19 February this year at the age of 46.

\section{THE BULLETIN OF THE BRITISH MUSEUM (NATURAL HISTORY)}

Unlike the usual research journal the Bulletins of the British Museum (Natural History) appear at irregular intervals and each is a comprehensive monograph on a specific subject.

\section{IMPORTANT TITLES FOR THIS SPRING}

THE OSTEOLOGY OF NOTELOPS WOODWARD, RHACOLEPIS AGASSIZ AND PACHYRHIZODUS DIXON (PISCES: TELEOSTEI)

P. L. Forey

Bull. B.M.(N.H.) Geology series Vol.28 pt. 2

Pp. 123-206, 39 figures $\mathbf{£ 7 . 5 0}$ post free

\section{EVOLUTIONARY TRENDS IN SOME MESOZOIC TEREBRATELLACEA}

\section{E. F. Owen}

Bull. B.M.(N.H.) Geology series

Vol. 28 pt. 3

Pp. 207-253, 3 plates, 29 figures $\mathbf{8 . 1 0}$ post free

\section{THE ACCACOELIIDAE (DIGENA) OF FISHES FROM THE NORTH-EAST ATLANTIC}

R. A. Bray and D. I. Gibson

Bull. B.M.(N.H.) Zoology series

Vol.31 pt. 2

Pp.51-99, 15 figures $\quad \mathbf{\$ 4 . 2 0}$ post free

THE PLANKTONIC COPEPODS

OF THE NORTHEASTERN

ATLANTIC OCEAN: SOME

TAXONOMIC OBSERVATIONS

ON THE ONCAEIDAE

(CYCLOPOIDA)

\section{G. A. Boxshal}

Bull. B.M.(N.H.) Zoology series

Vol.31 pt. 3

Pp.101-155, 25 figures $\mathbf{8 4 . 7 5}$ post free

NOTES ON DEEP/WATER

ATLANTIC CRINOIDEA

A. M. Clark

Bull. B.M.(N.H.) Zoology series

Vol.31 pt.4

Pp.157-186, 5 figures $£ 2.50$ post free

\section{A REVISION OF THE FAMILIES SYNNEURIDAE AND CANTHYLOSCELIDAE (DIPTERA)}

\section{A. M. Hutson}

Bull. B.M.(N.H.) Entomology series Vol. 35 pt.3

Pp.65-100, 26 figures $£ 3.00$ post free

STUDIES IN THE GENUS

HYPERICUM $L$. (GUTTIFERAE).

\section{INFRAGENERIC}

\section{CLASSIFICATION}

\section{N. K. B. Robson}

Bull. B.M.(N.H.) Botany series

Vol. 5 pt. 6

Pp.291-360 approx

approx. $\mathbf{6 6 . 5 0}$ post free

Obtainable from bookshops, approved agents, the Museum Bookshop, or by post direct from: Publications Sales, British Museum (Natural History) Cromwell Road, London SW7 5BD. 